\title{
Vitamin D and the Epithelial to Mesenchymal Transition
}

\author{
María Jesús Larriba, ${ }^{1}$ Antonio García de Herreros, ${ }^{2,3}$ and Alberto Muñoz ${ }^{1}$ \\ ${ }^{1}$ Instituto de Investigaciones Biomédicas "Alberto Sols", Consejo Superior de Investigaciones Científicas, Universidad Autónoma de \\ Madrid, IdiPAZ, 28029 Madrid, Spain \\ ${ }^{2}$ Institut Hospital del Mar d'Investigacions Mèdiques, 08003 Barcelona, Spain \\ ${ }^{3}$ Departament de Ciències Experimentals i de la Salut, Universitat Pompeu Fabra, 08003 Barcelona, Spain
}

Correspondence should be addressed to María Jesús Larriba; mjlarriba@iib.uam.es and Alberto Muñoz; amunoz@iib.uam.es

Received 4 September 2015; Accepted 8 November 2015

Academic Editor: Damian Medici

Copyright ( 2016 María Jesús Larriba et al. This is an open access article distributed under the Creative Commons Attribution License, which permits unrestricted use, distribution, and reproduction in any medium, provided the original work is properly cited.

\begin{abstract}
Several studies support reciprocal regulation between the active vitamin $\mathrm{D}$ derivative $1 \alpha, 25$-dihydroxyvitamin $\mathrm{D}_{3}\left(1,25(\mathrm{OH})_{2} \mathrm{D}_{3}\right)$ and the epithelial to mesenchymal transition (EMT). Thus, $1,25(\mathrm{OH})_{2} \mathrm{D}_{3}$ inhibits EMT via the induction of a variety of target genes that encode cell adhesion and polarity proteins responsible for the epithelial phenotype and through the repression of key EMT inducers. Both direct and indirect regulatory mechanisms mediate these effects. Conversely, certain master EMT inducers inhibit $1,25(\mathrm{OH})_{2} \mathrm{D}_{3}$ action by repressing the transcription of $V D R$ gene encoding the high affinity vitamin $\mathrm{D}$ receptor that mediates $1,25(\mathrm{OH})_{2} \mathrm{D}_{3}$ effects. Consequently, the balance between the strength of $1,25(\mathrm{OH})_{2} \mathrm{D}_{3}$ signaling and the induction of EMT defines the cellular phenotype in each context. Here we review the current understanding of the genes and mechanisms involved in the interplay between $1,25(\mathrm{OH})_{2} \mathrm{D}_{3}$ and EMT.
\end{abstract}

\section{The Vitamin D System}

The mammalian form of vitamin $\mathrm{D}$ is the prohormone vitamin $\mathrm{D}_{3}$ (cholecalciferol), which is obtained from the diet or mainly synthesized in the skin from 7-dehydrocholesterol through ultraviolet $\mathrm{B}$ radiation. Vitamin $\mathrm{D}_{3}$ is hydroxylated, first in the liver and then in the kidney and other tissues, to generate $1 \alpha, 25$-dihydroxyvitamin $\mathrm{D}_{3}\left(1,25(\mathrm{OH})_{2} \mathrm{D}_{3}\right.$, calcitriol), the most active vitamin $\mathrm{D}_{3}$ metabolite [1-5]. $1,25(\mathrm{OH})_{2} \mathrm{D}_{3}$ is a major regulator of gene expression and exerts its effects by binding to a transcription factor of the nuclear receptor superfamily: the vitamin $\mathrm{D}$ receptor (VDR). VDR heterodimerizes with another member of the same family, the retinoid $\mathrm{X}$ receptor, and regulates gene expression in a ligand-dependent manner. The prevailing model holds that in the absence of $1,25(\mathrm{OH})_{2} \mathrm{D}_{3}$ the heterodimer is bound to specific sequences on its target genes (vitamin $\mathrm{D}$ response elements) and to transcriptional corepressors that recruit complexes with histone deacetylase activity, thus maintaining the chromatin in a transcriptionally repressed state. $1,25(\mathrm{OH})_{2} \mathrm{D}_{3}$ induces conformational changes in VDR that cause the release of corepressors and the binding of coactivators and chromatin remodelers. Together they mediate chromatin opening and permit the entry of the basal RNA polymerase II transcription machinery and transcription initiation $[1,6-9]$.

$1,25(\mathrm{OH})_{2} \mathrm{D}_{3}$ is a pleiotropic hormone with many regulatory effects. It was classically known for its action on calcium and phosphorus homeostasis and bone mineralization $[2,10]$. The seminal discoveries in 1981 that $1,25(\mathrm{OH})_{2} \mathrm{D}_{3}$ induced myeloid leukemia cell differentiation and inhibited melanoma cell proliferation prompted the interest in $1,25(\mathrm{OH})_{2} \mathrm{D}_{3}$ as an anticancer agent $[11,12]$. Subsequent observations have shown that $1,25(\mathrm{OH})_{2} \mathrm{D}_{3}$ induces differentiation and apoptosis and inhibits proliferation, migration, invasion, and angiogenesis in cancer cells of different origin and in several animal models of cancer $[1,5,13-$ 16]. However, the administration of $1,25(\mathrm{OH})_{2} \mathrm{D}_{3}$ to cancer patients is restricted by its hypercalcemic effects at the therapeutic doses, enforcing the development of several analogs that maintain the antitumoral properties but have less calcemic actions. Currently, numerous clinical trials 
are ongoing using $1,25(\mathrm{OH})_{2} \mathrm{D}_{3}$ or its analogs, alone or in combination with other anticancer agents, against several neoplasms (https://www.clinicaltrials.gov/) [1, 4, 5, 13].

\section{Epithelial to Mesenchymal Transition}

Epithelial to mesenchymal transition (EMT) is the process by which epithelial cells are converted into mesenchymal cells. It takes place physiologically in several developmental situations such as mesoderm formation and neural crest migration. In the adult, it is reactivated in certain pathological conditions such as wound healing, fibrosis, and cancer progression [17, 18]. During EMT, epithelial cells lose cell-cell and cell-extracellular matrix junctions, change from an apicalbasal to a front-rear polarity, reorganize their cytoskeleton, and undergo a gene expression reprogramming characterized by the downregulation of the epithelial gene signature and the activation of mesenchymal genes. This process generates motile individual cells that can degrade the extracellular matrix and thus develop a migratory and invasive phenotype [18-21]. EMT is a highly regulated, plastic, and reversible process. Thus, the mesenchymal to epithelial transition (MET) occurs under certain conditions and enables that mesenchymal cells acquire an epithelial state [22-25].

Typical EMT gene reprogramming is mainly orchestrated by key transcription factors including the zinc finger proteins SNAIL1 and SNAIL2, the double zinc finger and homeodomain factors ZEB1 and ZEB2, and the members of the basic-helix-loop-helix family TWIST1 and E47, all known as EMT transcription factors (EMT-TFs). They are repressors of E-cadherin (encoded by $\mathrm{CDH1}$ ), that is the main component of adherens junctions and essential for the maintenance of the epithelial state. Thus, E-cadherin downregulation is considered a hallmark of EMT. In addition to the established EMT inducers, other transcription factors such as FOXC2, Goosecoid, KLF8, TCF4 (also known as E2-2), SIX1, HMGA2, Brachyury, and PRRX1 have been recently shown to induce or regulate EMT [18-21, 24]. Expression and/or activity of the transcription factors that drive EMT is induced and controlled by several signaling pathways that respond to extracellular cues, with a prominent role for transforming growth factor- (TGF-) $\beta$ signaling. The contribution of each transcription factor to the EMT depends on the cell or tissue type involved and the signaling pathway that initiates the EMT. Moreover, EMT-TFs often exhibit reciprocal control of their expressions and functional cooperation [18-20, 22, 23].

\section{3. $1,25(\mathrm{OH})_{2} \mathrm{D}_{3}$ Inhibits EMT}

3.1. $1,25(\mathrm{OH})_{2} \mathrm{D}_{3}$ Induces the Expression of Epithelial Markers. $1,25(\mathrm{OH})_{2} \mathrm{D}_{3}$ induces epithelial differentiation in several normal and cancer cells. Accordingly, it increases the expression of components of almost all types of cell adhesion structures that are essential for the acquisition and maintenance of the epithelial phenotype (Table 1). Remarkably, we found that the strong prodifferentiation effect of $1,25(\mathrm{OH})_{2} \mathrm{D}_{3}$ in human colon cancer cells is associated with an increase in the expression of the key adhesion molecule E-cadherin. This is accompanied by the redistribution of $\beta$-catenin from the cell nucleus to the adherens junctions at the plasma membrane where it interacts with E-cadherin, thus inhibiting the Wnt/ $\beta$ catenin signaling pathway that is aberrantly activated in most colon tumors and required for colon carcinogenesis [26]. In human colon cancer cells, $1,25(\mathrm{OH})_{2} \mathrm{D}_{3}$ also induces the expression of the tight junction components occludin, claudin-1, claudin-2, claudin-7, claudin-12, zonula occludens(ZO-) 1 and ZO-2, the desmosomal protein plectin, the focal adhesion members integrin $\alpha_{3}$ and paxillin, the constituent of intermediate filaments keratin-13, and proteins associated with the actin cytoskeleton such as vinculin, filamin A, and ezrin $[26,27,29-31,49,50]$. Interestingly, $1,25(\mathrm{OH})_{2} \mathrm{D}_{3}$ downregulates cadherin-17 [72], which induces cell proliferation and has protumoral and prometastatic effects in colon cancer cells [73].

Treatment of the $A p c^{\mathrm{min} /+}$ colon cancer mouse model with $1,25(\mathrm{OH})_{2} \mathrm{D}_{3}$ or analogs reduces polyp number and load, while it increases E-cadherin levels and reduces $\beta$ catenin nuclear localization and the expression of the $\beta$ catenin target genes $T c f 1, M y c$, and $C d 44$ in the small intestine and colon [32]. Conversely, $V d r$ deficiency in $A p c^{\mathrm{min} /+}$ mice enhances tumor size and the activity of the Wnt/ $\beta$-catenin pathway in the lesions $[65,74]$. Similar results were observed in other mouse and rat models of colon dysplasia, colon cancer, and colitis-associated neoplasia when treated with vitamin $\mathrm{D}_{3}$ or $1,25(\mathrm{OH})_{2} \mathrm{D}_{3}$ analogs $[33,63,64]$. Moreover, $1,25(\mathrm{OH})_{2} \mathrm{D}_{3}$ increases and restores the normal level of $\mathrm{Zo}$ 1 , occludin, and claudin-1 proteins in the colonic epithelium of the dextran sulfate sodium- (DSS-) induced colitis mouse model, protecting mice from intestinal mucosa injury and epithelial barrier disruption [27]. Conversely, $V d r$ deficiency potentiates DSS effects in this model, as DSS-treated $\mathrm{Vdr}^{-/-}$ mice have severely disrupted and opened tight junctions and desmosomes in the colonic epithelium and develop more severe colitis than wild-type animals [29]. These data indicate that $1,25(\mathrm{OH})_{2} \mathrm{D}_{3}$ contributes to the homeostasis and healing capacity of the colonic epithelium by preserving the stability and structural integrity of tight junctions [75]. Remarkably, a randomized, double-blind, placebo-controlled clinical trial showed that daily treatment of colorectal adenoma patients with 800 IU of vitamin $D_{3}$ for 6 months increases E-cadherin expression in normal-appearing rectal mucosa $[34,76]$.

In addition to colon cancer, E-cadherin is induced by $1,25(\mathrm{OH})_{2} \mathrm{D}_{3}$ or analogs in normal mammary and bronchial epithelial cells and in tumor cell lines derived from breast, prostate, non-small cell lung, and squamous cell carcinomas, usually associated with an increase in epithelial differentiation, a reduction in cell migration and invasion, and the inhibition of $\mathrm{Wnt} / \beta$-catenin signaling [35-41, 61, 77, 78]. We have described that the mechanism of E-cadherin induction by $1,25(\mathrm{OH})_{2} \mathrm{D}_{3}$ in human colon cancer cells is transcriptional indirect and requires the transient activation of the RhoA-ROCK-p38MAPK-MSK1 signaling pathway [26, 31]. Phosphatidylinositol 5-phosphate 4-kinase type II $\beta$ is also needed for E-cadherin induction by $1,25(\mathrm{OH})_{2} \mathrm{D}_{3}$ in colon cancer cells [79]. In agreement with the transcriptional regulation, Lopes et al. showed that $1,25(\mathrm{OH})_{2} \mathrm{D}_{3}$ treatment causes partial demethylation of $\mathrm{CpG}$ sites of $\mathrm{CDH} 1$ promoter in MDA-MB-231 triple-negative breast cancer cells [78]. 
TABLE 1: List of $1,25(\mathrm{OH})_{2} \mathrm{D}_{3}$-regulated proteins involved in EMT.

\begin{tabular}{|c|c|c|}
\hline Protein & $1,25(\mathrm{OH})_{2} \mathrm{D}_{3}$ effect & Reference \\
\hline \multicolumn{3}{|c|}{ Tight junction components } \\
\hline Occludin & Upregulation & [26-28] \\
\hline Claudin-1 & Upregulation & {$[27,29]$} \\
\hline Claudin-2 & Upregulation & {$[29,30]$} \\
\hline Claudin-7 & Upregulation & {$[31]$} \\
\hline Claudin-12 & Upregulation & [30] \\
\hline $\mathrm{ZO}-1$ & Upregulation & {$[26,27,29]$} \\
\hline $\mathrm{ZO}-2$ & Upregulation & {$[26]$} \\
\hline \multicolumn{3}{|c|}{ Adherens junction proteins } \\
\hline E-cadherin & Upregulation & {$[26,29,31-46]$} \\
\hline $\mathrm{N}$-cadherin & Downregulation & {$[37,41,42,47,48]$} \\
\hline P-cadherin & Downregulation & [37] \\
\hline Vinculin & Upregulation & {$[26,31]$} \\
\hline \multicolumn{3}{|c|}{ Focal adhesion members } \\
\hline Integrin $\alpha_{3}$ & Upregulation & {$[31]$} \\
\hline Integrin $\alpha_{\mathrm{V}}$ & Upregulation & [37] \\
\hline Integrin $\beta_{5}$ & Upregulation & [37] \\
\hline Integrin $\alpha_{6}$ & Downregulation & [37] \\
\hline Integrin $\beta_{4}$ & Downregulation & [37] \\
\hline Paxillin & Upregulation & {$[31,37]$} \\
\hline FAK & Upregulation & {$[37]$} \\
\hline \multicolumn{3}{|c|}{ Cytoskeleton-related proteins } \\
\hline Filamin A & Upregulation & [49] \\
\hline Ezrin & Upregulation & {$[50]$} \\
\hline$\alpha$-SMA & Downregulation & {$[37,43-46,51-54$} \\
\hline Keratin-13 & Upregulation & [49] \\
\hline Vimentin & Downregulation & {$[40-42]$} \\
\hline Plectin & Upregulation & [49] \\
\hline \multicolumn{3}{|c|}{ Extracellular matrix proteins } \\
\hline Fibronectin & Downregulation & {$[44,45,51,54]$} \\
\hline Collagen type I & Downregulation & {$[44,45,51,53-57]$} \\
\hline Collagen type II & Downregulation & {$[56]$} \\
\hline Collagen type III & Downregulation & {$[44,51,54,58]$} \\
\hline \multicolumn{3}{|l|}{ MMPs and inhibitors } \\
\hline MMP2 & Downregulation & {$[39,41,42]$} \\
\hline MMP9 & Downregulation & {$[39,41,42,59,60]$} \\
\hline MMP13 & Downregulation & {$[48,61]$} \\
\hline TIMP1 & Upregulation & {$[59,60]$} \\
\hline TIMP2 & Upregulation & [59] \\
\hline \multicolumn{3}{|l|}{ EMT-TFs } \\
\hline SNAIL1 & Downregulation & {$[40-42,44,61,62$} \\
\hline SNAIL2 & Downregulation & {$[42,61,62]$} \\
\hline ZEB1 & Downregulation & {$[40]$} \\
\hline TWIST1 & Downregulation & {$[61]$} \\
\hline \multicolumn{3}{|c|}{$\mathrm{Wnt} / \beta$-catenin target genes } \\
\hline MYC & Downregulation & {$[26,32,63,64]$} \\
\hline TCF1 & Downregulation & {$[26,32]$} \\
\hline $\mathrm{CD} 44$ & Downregulation & {$[26,32]$} \\
\hline Cyclin D1 & Downregulation & {$[31,33,55,64]$} \\
\hline
\end{tabular}

TABle 1: Continued.

\begin{tabular}{lcc}
\hline Protein & $1,25(\mathrm{OH})_{2} \mathrm{D}_{3}$ effect & Reference \\
\hline AXIN2 & Downregulation & {$[65]$} \\
LEF1 & Downregulation & {$[65]$} \\
Other EMT-related proteins & & \\
JMJD3 & Upregulation & {$[66]$} \\
Cystatin D & Upregulation & {$[67]$} \\
Cathepsin L & Downregulation & {$[68]$} \\
Sprouty-2 & Downregulation & {$[69]$} \\
PIT1 & Downregulation & {$[70]$} \\
IL-1 $\beta$ & Downregulation & {$[71]$} \\
TGF- $\beta$ & Downregulation & {$[44,54,56,58]$} \\
TGF- $\beta$ receptor type I & Downregulation & {$[44]$} \\
Cadherin-17 & Downregulation & {$[72]$} \\
\hline
\end{tabular}

Moreover, protein kinase $\mathrm{C}$ inhibitors block E-cadherin, $\mathrm{P}$ cadherin, $\alpha$-catenin, and vinculin translocation to cell-cell contacts and the assembly of adherens junctions promoted by $1,25(\mathrm{OH})_{2} \mathrm{D}_{3}$ in cultured human keratinocytes [80].

We reported that $1,25(\mathrm{OH})_{2} \mathrm{D}_{3}$ induces cell adhesion, inhibits cell migration and invasion, and profoundly affects the phenotype of human breast cancer cells [37]. It promotes the formation of focal adhesions by increasing the expression of integrin $\alpha_{\mathrm{V}}$, integrin $\beta_{5}$, paxillin, and focal adhesion kinase (FAK) proteins and also by inducing FAK phosphorylation. Additionally, $1,25(\mathrm{OH})_{2} \mathrm{D}_{3}$ reduces the expression of the mesenchymal marker $\mathrm{N}$-cadherin and the myoepithelial proteins P-cadherin, integrin $\alpha_{6}$, integrin $\beta_{4}$, and $\alpha$-smooth muscle actin $\left(\alpha\right.$-SMA). Thus, $1,25(\mathrm{OH})_{2} \mathrm{D}_{3}$ reverts the myoepithelial features that are associated with more aggressive and lethal forms of human breast cancer [37]. Likewise, $\mathrm{N}$-cadherin expression is strongly suppressed by $1,25(\mathrm{OH})_{2} \mathrm{D}_{3}$ in mouse osteoblast-like cells [47]. In line with these data, $1,25(\mathrm{OH})_{2} \mathrm{D}_{3}$ treatment blocks the EMT-associated cadherin switch (from E-cadherin to N-cadherin) in pancreatic cancer cells [42]. Notably, $1,25(\mathrm{OH})_{2} \mathrm{D}_{3}$ enhances corneal epithelial barrier function as corneal epithelial cells treated with $1,25(\mathrm{OH})_{2} \mathrm{D}_{3}$ show increased occludin levels, reduced permeability, and elevated transepithelial resistance, a measure of the functional integrity of tight junctions [28].

3.2. $1,25(\mathrm{OH})_{2} D_{3}$ Inhibits the Expression of EMT-TFs. We and others have reported that $1,25(\mathrm{OH})_{2} \mathrm{D}_{3}$ regulates the expression of certain transcription factors that induce EMT and of several modulators of the epithelial phenotype that can in fluence the expression of the EMT inducers (Table 1). 1,25(OH) ${ }_{2} \mathrm{D}_{3}$ increases by a transcriptional indirect mechanism the expression of Jumonji Domain Containing 3 (JMJD3), a histone H3 lysine 27 demethylase with putative tumor suppressor activity. JMJD3 mediates the induction of a highly adhesive epithelial phenotype, the antiproliferative effect, the gene regulatory action, and the antagonism of the $\mathrm{Wnt} / \beta$-catenin pathway promoted by $1,25(\mathrm{OH})_{2} \mathrm{D}_{3}$ in human colon cancer cells [66]. Moreover, JMJD3 depletion upregulates SNAIL1, ZEB1, and ZEB2, increases the expression of the mesenchymal markers fibronectin and LEF1, and downregulates 
the epithelial proteins E-cadherin, claudin-1, and claudin-7. Accordingly, JMJD3 and SNAIL1 RNA expression correlate inversely in samples from human colon cancer patients [66]. The induction of ZEB1 by JMJD3 depletion is associated with the downregulation of $m i R-200 b$ and $m i R-200 c$, two microRNAs that target ZEB1 RNA and inhibit ZEB1 protein expression [81].

$1,25(\mathrm{OH})_{2} \mathrm{D}_{3}$ directly induces the expression of cystatin $\mathrm{D}$, an inhibitor of cysteine proteases of the cathepsin family encoded by CST5 gene. The binding of VDR to the CST5 promoter induced by $1,25(\mathrm{OH})_{2} \mathrm{D}_{3}$ is accompanied by the release of the NCOR2 corepressor and an increase in histone $\mathrm{H} 4$ acetylation [67]. We found that cystatin D mediates the antiproliferative and prodifferentiation action of $1,25(\mathrm{OH})_{2} \mathrm{D}_{3}$ in human colon cancer cells. In addition, ectopic cystatin $\mathrm{D}$ expression inhibits proliferation, migration, anchorage-independent growth, and the $\mathrm{Wnt} / \beta$-catenin pathway in cultured colon cancer cells and reduces tumor development in xenografted mice [67]. Cystatin D represses SNAIL1, SNAIL2, ZEB1, and ZEB2, whereas it induces the expression of E-cadherin and other adhesion proteins such as occludin and p120-catenin. Accordingly, cystatin D and E-cadherin protein expression directly correlate in human colorectal cancer, and loss of cystatin D is associated with poor tumor differentiation [67]. Notably, transcriptomic and proteomic studies comparing cystatin D-overexpressing and mock-transfected human colon cancer cells indicated that "cell adhesion, cell junction, and cytoskeleton" is one of the gene categories that englobes more cystatin D-regulated genes and proteins [82]. Remarkably, Swami et al. showed that the expression of cathepsin L, whose activity is inhibited by cystatin $\mathrm{D}$, is downregulated by $1,25(\mathrm{OH})_{2} \mathrm{D}_{3}$ in breast cancer cells [68], while Zhang et al. described that silencing of cathepsin L suppresses the cell invasion and migration, the actin cytoskeleton remodeling, and the increase in SNAIL1 expression associated with TGF- $\beta$-promoted EMT in breast and lung cancer cells [83].

$1,25(\mathrm{OH})_{2} \mathrm{D}_{3}$ reduces the expression of Sprouty-2, an intracellular modulator of growth factor tyrosine kinase receptor signaling involved in the regulation of cell growth, migration, and angiogenesis [69]. Sprouty-2 strongly inhibits the induction of intercellular adhesion and E-cadherin protein expression promoted by $1,25(\mathrm{OH})_{2} \mathrm{D}_{3}$, and gain- and loss-offunction experiments indicate that Sprouty-2 and E-cadherin repress each other in colon cancer cells. Accordingly, the protein expression levels of Sprouty-2 and E-cadherin correlate inversely in cultured and xenografted colon cancer cells and in biopsies from human colon cancer patients. In line with this, we found that Sprouty-2 induces ZEB1 expression without affecting ZEB2, SNAIL1, or SNAIL2 levels [69]. ZEB1 upregulation by Sprouty-2 results from the induction of the transcription factor ETS1 and the repression of several microRNAs ( $m i R-200$ family and $m i R-150)$ that target ZEB1 RNA. Through ZEB1 upregulation, Sprouty-2 represses Ecadherin, claudin-7, occludin, the tight junction modulator matriptase, the cell adhesion molecule EPCAM, and the epithelial splicing regulatory protein ESRP1 that inhibits EMT [84]. Taken together, these data point to Sprouty-2 as a potent inhibitor of the epithelial phenotype that is downregulated by $1,25(\mathrm{OH})_{2} \mathrm{D}_{3}$ in colon carcinoma cells.
Recently, effects of $1,25(\mathrm{OH})_{2} \mathrm{D}_{3}$ on the expression of several EMT-TFs have been described. $1,25(\mathrm{OH})_{2} \mathrm{D}_{3}$ inhibits SNAIL1 and ZEB1 expression in non-small cell lung carcinoma cells, accompanied by an increase in E-cadherin expression, vimentin downregulation, maintenance of the epithelial morphology, and inhibition of cell migration [40]. The low calcemic $1,25(\mathrm{OH})_{2} \mathrm{D}_{3}$ analog MART-10 inhibits EMT and cell migration and invasion in breast and pancreatic cancer cells through the downregulation of SNAIL1 and SNAIL2. In addition, MART-10 inhibits TWIST1 expression in breast cancer cells $[42,61]$. Accordingly, Findlay et al. reported the inhibition of SNAIL1 and SNAIL2 by $1,25(\mathrm{OH})_{2} \mathrm{D}_{3}$ in human colon cancer cells [62]. Kaler et al. found that colon cancer cells stimulate tumor-associated macrophages to secrete interleukin- (IL-) $1 \beta$, which in turn promotes $\mathrm{Wnt} / \beta$-catenin signaling, stabilizes SNAIL1 protein, and confers resistance to TRAIL-induced apoptosis in colon cancer cells [71]. They also found that $1,25(\mathrm{OH})_{2} \mathrm{D}_{3}$, by inhibiting the release of IL- $1 \beta$ by macrophages, downregulates SNAIL1 protein expression in colon cancer cells [71]. Similarly, Zhang et al. showed that tumor-associated macrophages induce EMT in breast cancer cells and that high VDR expression in cancer cells abrogates the macrophage-promoted E-cadherin loss, $\alpha$-SMA upregulation, and increase in cell migration and invasion [43]. Furthermore, $1,25(\mathrm{OH})_{2} \mathrm{D}_{3}$ attenuates the enhancing effect of TGF- $\beta 1$ on cell motility and on SNAIL1, N-cadherin, and vimentin expression in human bronchial epithelial cells [41] and inhibits the TGF- $\beta 1$-stimulated EMT in rat lung epithelial cells [51].

Matrix metalloproteases (MMPs) are a family of zincdependent proteases that degrade components of the extracellular matrix and basement membrane. MMPs are regulated by the action of specific inhibitors: the tissue inhibitors of metalloproteases (TIMPs). Increased MMP activity is often associated with the EMT and confers invasive properties to cancer cells. Consistently with its inhibitory effect on EMT, $1,25(\mathrm{OH})_{2} \mathrm{D}_{3}$ downregulates the secretion of MMP2, MMP9, and MMP13 in prostate, breast, pancreatic, and squamous cell carcinoma cells and increases TIMP1 and TIMP2 activity in prostate and breast cancer cells [39, 42, 48, 59-61]. In addition, $1,25(\mathrm{OH})_{2} \mathrm{D}_{3}$ reduces the increase in MMP2 and MMP9 induced by TGF- $\beta 1$ in human bronchial epithelial cells [41]. Through these mechanisms, $1,25(\mathrm{OH})_{2} \mathrm{D}_{3}$ inhibits the capacity of cancer cells to degrade the extracellular matrix and invade the surrounding tissue and may thus reduce tumor cell metastatic potential. Remarkably, several studies from Pérez-Fernández's group have demonstrated that $1,25(\mathrm{OH})_{2} \mathrm{D}_{3}$ represses the expression of the gene encoding the pituitary transcription factor 1(PIT1) in breast cancer cells and that PIT1 silencing downregulates SNAIL1, MMP1, and MMP13 proteins $[70,85,86]$. In agreement with this, high PIT1 protein expression correlates with elevated MMP1 and MMP13 levels, SNAIL1 protein expression, and presence of distant metastasis in invasive ductal breast carcinoma [85, 86].

Recent studies have established a link between the induction of EMT and the acquisition by epithelial cells of molecular and functional traits of stem cells. As stem cells can both self-renew and differentiate, these stemness-related 
properties confer tumor-initiating capacities to carcinoma cells that could be crucial for cancer cell survival during dissemination and for the establishment by the disseminated cancer cells of metastatic foci at anatomically distant sites [1925]. Interestingly, Pervin et al. found that manipulation of VDR levels modulates the expression of key EMT-related proteins and dictates the stem cell characteristics of breast cancer cells. Thus, VDR overexpression in these cells upregulates E-cadherin, downregulates SNAIL1, TWIST1, and MMP9, and reduces cell ability to form mammospheres, an attribute of breast normal and cancer stem cells. Conversely, VDR silencing has the opposite effect [87].

3.3. $1,25(\mathrm{OH})_{2} \mathrm{D}_{3}$ Inhibits Fibrosis. In addition to cancer progression, EMT is reactivated in adult life during other pathological processes such as organ fibrosis. This process occurs in certain epithelial tissues after trauma or inflammatory injury and is characterized by excessive deposition of extracellular matrix and increased fibrous connective tissue. In this context, the EMT is part of the repair program and originates fibroblasts and other related cells for tissue regeneration. However, the disease usually progresses and the organ is finally composed mainly of activated fibroblasts and extracellular matrix, which may eventually lead to organ failure. The EMT inducer TGF- $\beta$ is also involved in the fibrotic process $[17,23,88]$. Several studies from Liu's group showed that vitamin D compounds attenuate renal interstitial fibrosis by inhibiting EMT in tubular epithelial cells. These compounds decrease collagen and fibronectin deposition, downregulate the expression of SNAIL1, $\alpha$-Sma, $\beta$-catenin, TGF- $\beta 1$, and its type I receptor, reduce $\beta$-catenin nuclear localization, and preserve $\mathrm{Vdr}$ and E-cadherin levels in kidneys from an obstructive nephropathy mouse model that develops interstitial fibrosis. Moreover, treatment with vitamin $\mathrm{D}$ compounds or $V D R$ overexpression in human renal proximal tubular epithelial cells abolishes the EMT promoted by TGF- $\beta 1$, while $V D R$ silencing has a sensitizing effect [44, $45,89]$. Interestingly, combination of the $1,25(\mathrm{OH})_{2} \mathrm{D}_{3}$ analog paricalcitol with trandolapril, an inhibitor of the angiotensinconverting enzyme used as standard treatment for chronic kidney disease, leads to additive reduction of renal fibrosis in the obstructive nephropathy mouse model [90]. Additionally, Nolan et al. indicated that paricalcitol inhibits TGF- $\beta 1-$ induced tubular EMT also under the hypoxic conditions commonly associated with chronic kidney disease [46], and Kim et al. reported that it attenuates the tubular EMT exogenously induced by 4-hydroxy-2-hexenal, an aldehyde product of lipid peroxidation [52].

Beneficial effects of $1,25(\mathrm{OH})_{2} \mathrm{D}_{3}$ have also been reported in liver fibrosis. Hepatic stellate cells play a central role in liver fibrosis as upon injury-induced activation they proliferate and secrete many extracellular matrix components. Vitamin $\mathrm{D}$ compounds reduce extracellular matrix deposition and ameliorate liver fibrosis in rat and mouse models $[55,56]$. In addition, $1,25(\mathrm{OH})_{2} \mathrm{D}_{3}$ suppresses cell proliferation and downregulates cyclin D1 and $\alpha_{1}$ type I collagen expression in cultured hepatic stellate cells [55]. Potter et al. reported that the downregulation of $\alpha_{1}$ type I collagen by $1,25(\mathrm{OH})_{2} \mathrm{D}_{3}$ is mediated by VDR binding to a proximal $\mathrm{Spl}$ site and a distal vitamin D response element in the human COL1A1 gene promoter [57]. Notably, a study from Ding et al. revealed that ligand-activated VDR antagonizes TGF- $\beta 1$-dependent transcription of profibrotic genes in hepatic stellate cells [56]. TGF- $\beta 1$ changes ligand activated-VDR binding sites in the genome promoting VDR binding to SMAD3 sites in the regulatory regions of profibrotic genes, which decreases SMAD3 occupancy at these sites causing transcriptional silencing of the genes and inhibiting fibrosis [56]. Thus, VDR ligands limit fibrosis by modulating the tissue response to TGF- $\beta 1$. Ito et al. described that a similar mechanism takes place in renal fibrosis and showed that the C-terminal $\alpha$ helix 12 of the ligand-binding domain of VDR is necessary for the interaction with SMAD3 and the suppression of TGF$\beta$ pathway [53]. Furthermore, they designed VDR ligands that selectively inhibit TGF- $\beta$ signaling without activating VDR-mediated transcription and significantly attenuate renal fibrosis in mice without hypercalcemic effects [53]. Another mechanism involved in the inhibition of TGF- $\beta$ pathway by vitamin $\mathrm{D}$ analogs in renal fibrosis has been described: maxacalcitol blocks the autoinduction of TGF- $\beta 1$ expression through the recruitment of a complex between VDR and the SMAD3 phosphatase PPM1A to the TGFB1 promoter, causing SMAD3 dephosphorylation and release from the promoter and, consequently, attenuating TGFB1 gene expression [54].

Peritoneal dialysis induces changes in mesothelial cells that are reminiscent of those occurring during EMT, and that may finally lead to the development of fibrosis. Vitamin D compounds prevent the progression of peritoneal fibrosis in mouse and rat models and inhibit the TGF- $\beta 1$-induced EMTlike process in human peritoneal mesothelial cells $[58,91]$. Thus, a large body of evidence indicates that vitamin $\mathrm{D}$ compounds protect against organ fibrosis in different tissues by inhibiting EMT and/or TGF- $\beta$ profibrotic action.

\section{The Transcription Factors SNAIL1 and SNAIL2 Repress VDR Gene Expression and Inhibit 1,25( $(\mathrm{OH})_{2} \mathrm{D}_{3}$ Action}

Cell responsiveness to $1,25(\mathrm{OH})_{2} \mathrm{D}_{3}$ mainly relays on VDR expression levels. VDR protein is expressed in almost all normal human cell types and tissues, and also in cancer cell lines and tumors of several origins $[8,92]$. Remarkably, elevated VDR expression is associated with high tumor differentiation, absence of node involvement, and good prognosis in colon cancer [93-95], with lower tumor grade, late development of lymph node metastases, and longer disease-free survival in breast cancer [43, 96-98], and with improved overall survival in prostate and non-small cell lung cancer and melanoma [99-101]. However, certain cancer cell lines do not express VDR and are unresponsive to $1,25(\mathrm{OH})_{2} \mathrm{D}_{3}$. Accordingly, VDR downregulation has been observed in a proportion of melanomas and colon, breast, lung, and ovarian tumors $[43,94,99,102-104]$, which may jeopardize the response to therapy with vitamin $\mathrm{D}, 1,25(\mathrm{OH})_{2} \mathrm{D}_{3}$, or its analogs.

These lines of evidence prompted us to study the mechanisms responsible for VDR downregulation in cancer. We found that SNAIL1 represses the expression of VDR by binding to three E-boxes in the human VDR gene promoter. 
Moreover, SNAIL1 reduces VDR RNA half-life [105]. As a result, SNAIL1 overexpression in human colon cancer cells blocks the induction of E-cadherin expression and the acquisition of an epithelial phenotype promoted by $1,25(\mathrm{OH})_{2} \mathrm{D}_{3}$. Consequently, $\beta$-catenin is not relocated from the nucleus to the plasma membrane adherens junctions and the Wnt $/ \beta$ catenin signaling remains active. SNAIL1 also abrogates the inhibitory effect of $1,25(\mathrm{OH})_{2} \mathrm{D}_{3}$ on cell proliferation and migration in cultured cells and the antitumoral action of the $1,25(\mathrm{OH})_{2} \mathrm{D}_{3}$ analog EB1089 in xenografted mice [105, 106]. Consistently, Knackstedt et al. have shown that the downregulation of $V d r$ observed in the colon of DSS-induced colitis mouse model is associated with an increase in the expression of SNAIL1 and its upstream regulator tumor necrosis factor- (Tnf-) $\alpha$ [107].

In addition to SNAIL1, we reported that its family member SNAIL2 represses $V D R$ gene expression through the same E-boxes in the human VDR gene promoter and blocks the induction of an epithelial phenotype by $1,25(\mathrm{OH})_{2} \mathrm{D}_{3}$ in human colon cancer cells. Moreover, SNAIL1 and SNAIL2 show an additive repressive effect on VDR gene promoter [108]. Remarkably, SNAIL1 and/or SNAIL2 RNA upregulation was detected in $76 \%$ of colon tumors and significantly correlated with diminished VDR RNA expression. Indeed, the lowest VDR RNA levels were observed in those colon tumors that overexpress both EMT-TFs [95, 105, 108]. We also showed that SNAIL1 RNA overexpression in colon tumors diminishes $V D R$ RNA expression in the histologically normal tissue adjacent to the tumor, suggesting that SNAIL1expressing colon cancer cells secrete signals that modulate VDR expression in neighboring cells [109].

The repression of VDR gene by SNAIL factors is not exclusive to colon cancer. It has been shown that SNAILl and SNAIL2 downregulate $V D R$ gene expression and abrogate the antitumoral action of $1,25(\mathrm{OH})_{2} \mathrm{D}_{3}$ in human osteosarcoma and breast cancer cells [110, 111]. The two proximal E-boxes of the human $V D R$ gene promoter are conserved in rat and mouse, while the most distal box is only partially conserved with one base substitution. Bai et al. found SNAIL1 binding only to the most proximal E-box of the rat $V d r$ promoter accompanied by deacetylation of histone $\mathrm{H} 3$ in samples from rat intestine and kidney. Accordingly, an inverse correlation between SNAIL1 and $V d r$ levels was observed in those tissues [112]. de Frutos et al. showed that the sustained activation of SNAIL1 in transgenic mice represses $V d r$ gene expression in osteoblasts. This downregulation blocks the Vdr-mediated induction of the osteoclast differentiation factor Rankl and inhibition of osteoprotegerin, a decoy Rankl receptor that inhibits osteoclastogenesis. Thus, $V d r$ gene downregulation by SNAIL1 in osteoblasts reduces the osteoclast population due to an impaired osteoclastogenesis. In addition, chromatin immunoprecipitation assays indicated that $V d r$ gene repression in mouse osteoblasts is mediated by SNAIL1 binding to the two proximal E-boxes of murine $V d r$ promoter [113].

VDR downregulation takes place also and contributes to E-cadherin loss during the EMT promoted by the proinflammatory cytokine TNFSF12 in renal tubular epithelial cells [114]. Similarly, VDR repression by TNF- $\alpha$ sensitizes breast cancer cells to TGF- $\beta 1$-induced EMT. Of note, $1,25(\mathrm{OH})_{2} \mathrm{D}_{3}$ treatment protects against TNF- $\alpha$-induced VDR loss, suppresses TGF- $\beta 1$-promoted increase in the migration capacity of cultured breast cancer cells, and inhibits lung metastasis in an orthotopic breast cancer mouse model [43]. Conversely, the MET induced by the enforced reexpression of the putative tumor suppressor KLF4 in hepatocellular carcinoma cells was accompanied by VDR upregulation and an increase in the inhibitory effect of $1,25(\mathrm{OH})_{2} \mathrm{D}_{3}$ on cell proliferation. As a result, KLF4 and VDR protein expression correlate directly in human hepatocellular carcinoma [115].

Other EMT-TFs such as ZEB1, ZEB2, TWIST1, or E47 have no effect on the expression of human VDR gene promoter in SW480-ADH human colon cancer cells [108]. However, Lazarova et al. reported that ZEB1 binds to two distal E-boxes in the murine $V d r$ promoter and activates its expression in COS-7 monkey kidney fibroblasts and SW620 human colon cancer cells, but not in human LNCaP prostate or HCT116 colon cancer cells [116]. Other studies showed absence of correlation or a significant direct correlation between ZEB1 and VDR RNA expression in colon cancer $[95,109,117]$. Furthermore, Peña et al. observed that such direct correlation was stronger in colon tumors with high level of the transcriptional coactivator p300 [117]. Globally, these data suggest a cell- and context-dependent positive regulation of VDR by ZEB1.

\section{Conclusions and Perspectives}

Cell fate and phenotype are strictly regulated by extracellular signals. $1,25(\mathrm{OH})_{2} \mathrm{D}_{3}$ and EMT-TFs have opposite effects on epithelial cell phenotype and they antagonize each other (Figure 1). 1,25(OH) ${ }_{2} \mathrm{D}_{3}$ induces epithelial differentiation while it inhibits the expression of several EMT inducers. Conversely, expression of key EMT-TFs in epithelial cells promotes the acquisition of a mesenchymal phenotype, which in the case of SNAIL1 and SNAIL2 is associated with VDR gene repression and the blockade of $1,25(\mathrm{OH})_{2} \mathrm{D}_{3}$ action on epithelial differentiation. Thus, a double negative feedback loop operates between $1,25(\mathrm{OH})_{2} \mathrm{D}_{3}$ and EMT inducers that may contribute to the complete acquisition of the phenotype dictated by the extracellular cues. The loop may first amplify the signal and later stabilize cell fate once the process is completed. Hence, the balance between $1,25(\mathrm{OH})_{2} \mathrm{D}_{3} / \mathrm{VDR}$ and SNAIL family of transcription factors determines cell fate, and its imbalance may explain the reversibility of the EMT process. Of note, the transition between epithelial and mesenchymal phenotypes is also governed by similar double negative feedback loops among EMT-TFs and certain microRNAs, such as the ZEB/miR-200 and the SNAIL1/miR34 regulatory circuits $[22,118-120]$.

The implication of EMT in cancer progression and organ fibrosis and the inhibitory effect of $1,25(\mathrm{OH})_{2} \mathrm{D}_{3}$ on EMT have opened the possibility of a therapeutic use of VDR agonists against these diseases. However, the downregulation of VDR expression found in several types of cancer, frequently associated with advanced stages of the disease, limits the applicability of vitamin D compounds to prevention in highrisk populations and treatment in patients at early stages of tumor progression. In addition, EMT is a transient event during tumorigenesis, and it has been proposed that the reverse 


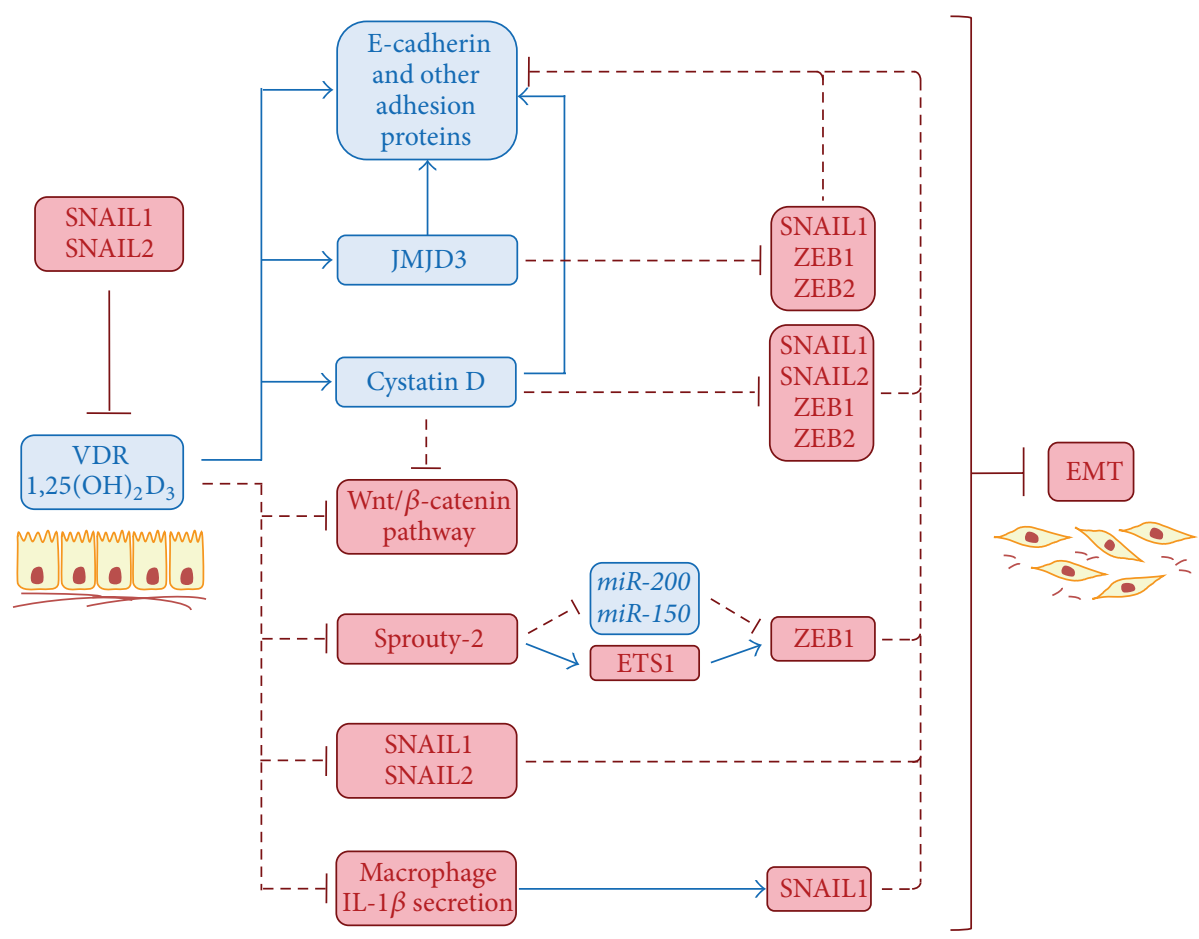

FIGURE 1: Scheme showing the mechanisms involved in the reciprocal regulation between $1,25(\mathrm{OH})_{2} \mathrm{D}_{3}$ and EMT in human colon cancer cells. Proteins and pathways displayed in blue are associated with an epithelial phenotype, while those shown in red are related with a mesenchymal phenotype. Blue and red lines are used to indicate induction or repression, respectively.

process (MET) is required for the establishment of metastasis at distant sites $[121,122]$. These lines of evidence have led to controversy about anticancer therapeutic strategies designed to inhibit EMT, as they may favor the formation of metastases, and suggest that these therapies may be limited to patients diagnosed at early stages of the disease to prevent invasion and dissemination [23]. Nevertheless, vitamin D compounds as inhibitors of EMT may be interesting therapeutic agents for fibrosis-associated pathologies, in which the EMT process is not reverted and the mesenchymal phenotype is maintained during disease progression.

\section{Conflict of Interests}

The authors declare that there is no conflict of interests regarding the publication of this paper.

\section{Acknowledgments}

The authors thank Robin Rycroft for his valuable assistance in the preparation of the English paper. The work in the authors' laboratories is supported by Ministerio de Economía y Competitividad of Spain-Fondo Europeo de Desarrollo Regional (FEDER) to Alberto Muñoz (SAF201343468-R), Instituto de Salud Carlos III-FEDER to Alberto Muñoz (RD12/0036/0021) and Antonio García de Herreros (RD12/0036/0005), and Comunidad de Madrid to Alberto Muñoz and Antonio García de Herreros (S2010/BMD-2344 Colomics2).

\section{References}

[1] K. K. Deeb, D. L. Trump, and C. S. Johnson, "Vitamin D signalling pathways in cancer: potential for anticancer therapeutics," Nature Reviews Cancer, vol. 7, no. 9, pp. 684-700, 2007.

[2] M. F. Holick, "Medical progress: vitamin D deficiency," New England Journal of Medicine, vol. 357, no. 3, pp. 266-281, 2007.

[3] F. C. Campbell, H. Xu, M. El-Tanani, P. Crowe, and V. Bingham, "The yin and yang of vitamin D receptor (VDR) signaling in neoplastic progression: operational networks and tissue-specific growth control," Biochemical Pharmacology, vol. 79, no. 1, pp. 1-9, 2010.

[4] L. A. Plum and H. F. DeLuca, "Vitamin D, disease and therapeutic opportunities," Nature Reviews Drug Discovery, vol. 9, no. 12, pp. 941-955, 2010.

[5] D. Feldman, A. V. Krishnan, S. Swami, E. Giovannucci, and B. J. Feldman, "The role of vitamin D in reducing cancer risk and progression," Nature Reviews Cancer, vol. 14, no. 5, pp. 342-357, 2014.

[6] C. Carlberg and S. Seuter, "A genomic perspective on vitamin D signaling," Anticancer Research, vol. 29, no. 9, pp. 3485-3493, 2009.

[7] M. R. Haussler, P. W. Jurutka, M. Mizwicki, and A. W. Norman, "Vitamin D receptor (VDR)-mediated actions of $1 \alpha, 25(\mathrm{OH})_{2}$ vitamin $\mathrm{D}_{3}$ : genomic and non-genomic mechanisms," Best Practice \& Research Clinical Endocrinology \& Metabolism, vol. 25, no. 4, pp. 543-559, 2011.

[8] C. J. Rosen, J. S. Adams, D. D. Bikle et al., "The nonskeletal effects of vitamin D: an endocrine society scientific statement," Endocrine Reviews, vol. 33, no. 3, pp. 456-492, 2012. 
[9] C. Carlberg and M. J. Campbell, "Vitamin D receptor signaling mechanisms: integrated actions of a well-defined transcription factor," Steroids, vol. 78, no. 2, pp. 127-136, 2013.

[10] A. Verstuyf, G. Carmeliet, R. Bouillon, and C. Mathieu, "Vitamin D: a pleiotropic hormone," Kidney International, vol. 78, no. 2, pp. 140-145, 2010.

[11] E. Abe, C. Miyaura, H. Sakagami et al., "Differentiation of mouse myeloid leukemia cells induced by $1 \alpha, 25$-dihydroxyvitamin D3," Proceedings of the National Academy of Sciences of the United States of America, vol. 78, no. 8 I, pp. 4990-4994, 1981.

[12] K. Colston, M. J. Colston, and D. Feldman, "1,25-Dihydroxyvitamin $\mathrm{D}_{3}$ and malignant melanoma: the presence of receptors and inhibition of cell growth in culture," Endocrinology, vol. 108, no. 3, pp. 1083-1086, 1981.

[13] A. V. Krishnan and D. Feldman, "Mechanisms of the anti-cancer and anti-inflammatory actions of vitamin D," Annual Review of Pharmacology and Toxicology, vol. 51, pp. 311-336, 2011.

[14] J. C. Fleet, M. Desmet, R. Johnson, and Y. Li, "Vitamin D and cancer: a review of molecular mechanisms," Biochemical Journal, vol. 441, no. 1, pp. 61-76, 2012.

[15] F. Pereira, M. J. Larriba, and A. Muñoz, "Vitamin D and colon cancer," Endocrine-Related Cancer, vol. 19, no. 3, pp. R51-R71, 2012.

[16] C. Leyssens, L. Verlinden, and A. Verstuy, "Antineoplastic effects of $1,25(\mathrm{OH})_{2} \mathrm{D}_{3}$ and its analogs in breast, prostate and colorectal cancer," Endocrine-Related Cancer, vol. 20, no. 2, pp. R31-R47, 2013.

[17] R. Kalluri and R. A. Weinberg, "The basics of epithelial-mesenchymal transition," The Journal of Clinical Investigation, vol. 119, no. 6, pp. 1420-1428, 2009.

[18] J. P. Thiery, H. Acloque, R. Y. J. Huang, and M. A. Nieto, "Epithelial-Mesenchymal Transitions in Development and Disease," Cell, vol. 139, no. 5, pp. 871-890, 2009.

[19] N. Tiwari, A. Gheldof, M. Tatari, and G. Christofori, "EMT as the ultimate survival mechanism of cancer cells," Seminars in Cancer Biology, vol. 22, no. 3, pp. 194-207, 2012.

[20] S. Lamouille, J. Xu, and R. Derynck, "Molecular mechanisms of epithelial-mesenchymal transition," Nature Reviews Molecular Cell Biology, vol. 15, no. 3, pp. 178-196, 2014.

[21] A. Puisieux, T. Brabletz, and J. Caramel, "Oncogenic roles of EMT-inducing transcription factors," Nature Cell Biology, vol. 16, no. 6, pp. 488-494, 2014.

[22] A. García de Herreros and J. Baulida, "Cooperation, amplification, and feed-back in epithelial-mesenchymal transition," Biochimica et Biophysica Acta-Reviews on Cancer, vol. 1825, no. 2, pp. 223-228, 2012.

[23] M. A. Nieto and A. Cano, "The epithelial-mesenchymal transition under control: global programs to regulate epithelial plasticity," Seminars in Cancer Biology, vol. 22, no. 5-6, pp. 361368, 2012.

[24] B. De Craene and G. Berx, "Regulatory networks defining EMT during cancer initiation and progression," Nature Reviews Cancer, vol. 13, no. 2, pp. 97-110, 2013.

[25] W. L. Tam and R. A. Weinberg, "The epigenetics of epithelialmesenchymal plasticity in cancer," Nature Medicine, vol. 19, no. 11, pp. 1438-1449, 2013.

[26] H. G. Pálmer, J. M. González-Sancho, J. Espada et al., "Vitamin $\mathrm{D}_{3}$ promotes the differentiation of colon carcinoma cells by the induction of E-cadherin and the inhibition of $\beta$-catenin signaling," The Journal of Cell Biology, vol. 154, no. 2, pp. 369$387,2001$.
[27] H. Zhao, H. Zhang, H. Wu et al., "Protective role of 1,25(OH) vitamin $\mathrm{D}_{3}$ in the mucosal injury and epithelial barrier disruption in DSS-induced acute colitis in mice," BMC Gastroenterology, vol. 12, article 57, 2012.

[28] Z. Yin, V. Pintea, Y. Lin, B. D. Hammock, and M. A. Watsky, "Vitamin D enhances corneal epithelial barrier function," Investigative Ophthalmology and Visual Science, vol. 52, no. 10, pp. 7359-7364, 2011.

[29] J. Kong, Z. Zhang, M. W. Musch et al., "Novel role of the vitamin $D$ receptor in maintaining the integrity of the intestinal mucosal barrier," American Journal of Physiology-Gastrointestinal and Liver Physiology, vol. 294, no. 1, pp. G208-G216, 2007.

[30] H. Fujita, K. Sugimoto, S. Inatomi et al., "Tight junction proteins claudin-2 and -12 are critical for vitamin D-dependent $\mathrm{Ca}^{2+}$ absorption between enterocytes," Molecular Biology of the Cell, vol. 19, no. 5, pp. 1912-1921, 2008.

[31] P. Ordóñez-Morán, M. J. Larriba, H. G. Pálmer et al., "RhoAROCK and $\mathrm{p} 38 \mathrm{MAPK}-\mathrm{MSK} 1$ mediate vitamin D effects on gene expression, phenotype, and Wnt pathway in colon cancer cells," The Journal of Cell Biology, vol. 183, no. 4, pp. 697-710, 2008.

[32] H. Xu, G. H. Posner, M. Stevenson, and F. C. Campbell, "Apc ${ }^{\mathrm{MIN}}$ modulation of vitamin D secosteroid growth control," Carcinogenesis, vol. 31, no. 8, pp. 1434-1441, 2010.

[33] R. K. Wali, S. Khare, M. Tretiakova et al., "Ursodeoxycholic acid and $\mathrm{F}_{6}-\mathrm{D}_{3}$ inhibit aberrant crypt proliferation in the rat azoxymethane model of colon cancer: roles of cyclin D1 and Ecadherin," Cancer Epidemiology, Biomarkers \& Prevention, vol. 11, no. 12, pp. 1653-1662, 2002.

[34] T. U. Ahearn, A. Shaukat, W. D. Flanders, R. E. Rutherford, and R. M. Bostick, "A randomized clinical trial of the effects of supplemental calcium and vitamin $\mathrm{D}_{3}$ on the APC/ $\beta$-catenin pathway in the normal mucosa of colorectal adenoma patients," Cancer Prevention Research, vol. 5, no. 10, pp. 1247-1256, 2012.

[35] M. J. Campbell, E. Elstner, S. Holden, M. Uskokovic, and H. P. Koeffler, "Inhibition of proliferation of prostate cancer cells by a 19-nor-hexafluoride vitamin D3 analogue involves the induction of $\mathrm{p} 21^{\text {waf } 1} \mathrm{p} 27^{\text {kip } 1}$ and E-cadherin," Journal of Molecular Endocrinology, vol. 19, no. 1, pp. 15-27, 1997.

[36] Q. Wang, D. Lee, V. Sysounthone et al., "1,25-Dihydroxyvitamin D3 and retonic acid analogues induce differentiation in breast cancer cells with function- and cell-specific additive effects," Breast Cancer Research and Treatment, vol. 67, no. 2, pp. 157168, 2001.

[37] N. Pendás-Franco, J. M. González-Sancho, Y. Suárez et al., "Vitamin D regulates the phenotype of human breast cancer cells," Differentiation, vol. 75, no. 3, pp. 193-207, 2007.

[38] H. Xu, M. McCann, Z. Zhang et al., "Vitamin D receptor modulates the neoplastic phenotype through antagonistic growth regulatory signals," Molecular Carcinogenesis, vol. 48, no. 8, pp. 758-772, 2009.

[39] Y. Ma, W.-D. Yu, B. Su et al., "Regulation of motility, invasion, and metastatic potential of squamous cell carcinoma by $1 \alpha, 25-$ dihydroxycholecalciferol," Cancer, vol. 119, no. 3, pp. 563-574, 2013.

[40] S. K. Upadhyay, A. Verone, S. Shoemaker et al., "1,25-Dihydroxyvitamin $\mathrm{D}_{3}\left(1,25(\mathrm{OH})_{2} \mathrm{D}_{3}\right)$ signaling capacity and the epithelial-mesenchymal transition in Non-Small Cell Lung Cancer (NSCLC): implications for use of $1,25(\mathrm{OH})_{2} \mathrm{D}_{3}$ in NSCLC treatment," Cancers, vol. 5, no. 4, pp. 1504-1521, 2013.

[41] K. D. Fischer and D. K. Agrawal, "Vitamin D regulating TGF- $\beta$ induced epithelial-mesenchymal transition," Respiratory Research, vol. 15, no. 1, article 146, 2014. 
[42] K.-C. Chiang, C.-N. Yeh, J.-T. Hsu et al., "The vitamin D analog, MART-10, represses metastasis potential via downregulation of epithelial-mesenchymal transition in pancreatic cancer cells," Cancer Letters, vol. 354, no. 2, pp. 235-244, 2014.

[43] Y. Zhang, Q. Guo, Z. Zhang et al., "VDR status arbitrates the prometastatic effects of tumor-associated macrophages," Molecular Cancer Research, vol. 12, no. 8, pp. 1181-1191, 2014.

[44] X. Tan, Y. Li, and Y. Liu, "Paricalcitol attenuates renal interstitial fibrosis in obstructive nephropathy," Journal of the American Society of Nephrology, vol. 17, no. 12, pp. 3382-3393, 2006.

[45] M. Xiong, J. Gong, Y. Liu, R. Xiang, and X. Tan, "Loss of vitamin $\mathrm{D}$ receptor in chronic kidney disease: a potential mechanism linking inflammation to epithelial-to-mesenchymal transition," The American Journal of Physiology - Renal Physiology, vol. 303, no. 7, pp. F1107-F1115, 2012.

[46] K. A. Nolan, E. P. Brennan, C. C. Scholz et al., "Paricalcitol protects against TGF- $\beta 1$-induced fibrotic responses in hypoxia and stabilises HIF- $\alpha$ in renal epithelia," Experimental Cell Research, vol. 330, no. 2, pp. 371-381, 2015.

[47] E. Luegmayr, H. Glantschnig, F. Varga, and K. Klaushofer, “The organization of adherens junctions in mouse osteoblast-like cells (MC3T3-E1) and their modulation by triiodothyronine and 1,25-dihydroxyvitamin D3," Histochemistry and Cell Biology, vol. 113, no. 6, pp. 467-478, 2000.

[48] R. Lin, Y. Nagai, R. Sladek et al., "Expression profiling in squamous carcinoma cells reveals pleiotropic effects of vitamin $\mathrm{D}_{3}$ analog EB1089 signaling on cell proliferation, differentiation, and immune system regulation," Molecular Endocrinology, vol. 16, no. 6, pp. 1243-1256, 2002.

[49] H. G. Pálmer, M. Sánchez-Carbayo, P. Ordóñez-Morán, M. J. Larriba, C. Cordón-Cardó, and A. Muñoz, "Genetic signatures of differentiation induced by $1 \alpha, 25$-dihydroxyvitamin D3 in human colon cancer cells," Cancer Research, vol. 63, no. 22, pp. 7799-7806, 2003.

[50] I. Cristobo, M. J. Larriba, V. de los Ríos, F. García, A. Muñoz, and J. I. Casal, "Proteomic analysis of $1 \alpha, 25$-dihydroxyvitamin $\mathrm{D}_{3}$ action on human colon cancer cells reveals a link to splicing regulation," Journal of Proteomics, vol. 75, no. 2, pp. 384-397, 2011.

[51] A. M. Ramirez, C. Wongtrakool, T. Welch, A. Steinmeyer, U. Zügel, and J. Roman, "Vitamin D inhibition of pro-fibrotic effects of transforming growth factor $\beta 1$ in lung fibroblasts and epithelial cells," Journal of Steroid Biochemistry and Molecular Biology, vol. 118, no. 3, pp. 142-150, 2010.

[52] C. S. Kim, S. Y. Joo, K. E. Lee et al., "Paricalcitol attenuates 4-hydroxy-2-hexenal-induced inflammation and epithelialmesenchymal transition in human renal proximal tubular epithelial cells," PLoS ONE, vol. 8, no. 5, Article ID e63186, 2013.

[53] I. Ito, T. Waku, M. Aoki et al., "A nonclassical vitamin D receptor pathway suppresses renal fibrosis," Journal of Clinical Investigation, vol. 123, no. 11, pp. 4579-4594, 2013.

[54] K. Inoue, I. Matsui, T. Hamano et al., "Maxacalcitol ameliorates tubulointerstitial fibrosis in obstructed kidneys by recruiting PPM1A/VDR complex to pSmad3," Laboratory Investigation, vol. 92, no. 12, pp. 1686-1697, 2012.

[55] S. Abramovitch, L. Dahan-Bachar, E. Sharvit et al., "Vitamin $\mathrm{D}$ inhibits proliferation and profibrotic marker expression in hepatic stellate cells and decreases thioacetamide-induced liver fibrosis in rats," Gut, vol. 60, no. 12, pp. 1728-1737, 2011.

[56] N. Ding, R. T. Yu, N. Subramaniam et al., "A vitamin D receptor/SMAD genomic circuit gates hepatic fibrotic response," Cell, vol. 153, no. 3, pp. 601-613, 2013.
[57] J. J. Potter, X. Liu, A. Koteish, and E. Mezey, "1,25-Dihydroxyvitamin D3 and its nuclear receptor repress human $\alpha_{1}$ (I) collagen expression and type I collagen formation," Liver International, vol. 33, no. 5, pp. 677-686, 2013.

[58] M. Hirose, T. Nishino, Y. Obata et al., "22-oxacalcitriol prevents progression of peritoneal fibrosis in a mouse model," Peritoneal Dialysis International, vol. 33, no. 2, pp. 132-142, 2013.

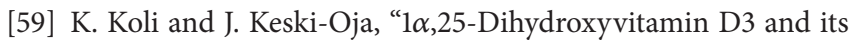
analogues down-regulate cell invasion-associated proteases in cultured malignant cells," Cell Growth \& Differentiation, vol. 11, no. 4, pp. 221-229, 2000.

[60] B.-Y. Bao, S.-D. Yeh, and Y.-F. Lee, " $1 \alpha, 25$-Dihydroxyvitamin $\mathrm{D}_{3}$ inhibits prostate cancer cell invasion via modulation of selective proteases," Carcinogenesis, vol. 27, no. 1, pp. 32-42, 2006.

[61] K.-C. Chiang, S.-C. Chen, C.-N. Yeh et al., "MART-10, a less calcemic vitamin $\mathrm{D}$ analog, is more potent than $1 \alpha, 25$-dihydroxyvitamin $\mathrm{D}_{3}$ in inhibiting the metastatic potential of MCF-7 breast cancer cells in vitro," Journal of Steroid Biochemistry and Molecular Biology, vol. 139, pp. 54-60, 2014.

[62] V. J. Findlay, R. E. Moretz, C. Wang et al., "Slug expression inhibits calcitriol-mediated sensitivity to radiation in colorectal cancer," Molecular Carcinogenesis, vol. 53, no. 1, pp. E130-E139, 2014.

[63] A. Fichera, N. Little, U. Dougherty et al., "A vitamin D analogue inhibits colonic carcinogenesis in the AOM/DSS model," Journal of Surgical Research, vol. 142, no. 2, pp. 239-245, 2007.

[64] W. Li, Q. L. Wang, X. Liu et al., "Combined use of vitamin D3 and metformin exhibits synergistic chemopreventive effects on colorectal neoplasia in rats and mice," Cancer Prevention Research, vol. 8, no. 2, pp. 139-148, 2015.

[65] M. J. Larriba, P. Ordóñez-Morán, I. Chicote et al., "Vitamin $\mathrm{D}$ receptor deficiency enhances $\mathrm{Wnt} / \beta$-catenin signaling and tumor burden in colon cancer," PLoS ONE, vol. 6, no. 8, Article ID e23524, 2011.

[66] F. Pereira, A. Barbáchano, J. Silva et al., "KDM6B/JMJD3 histone demethylase is induced by vitamin $\mathrm{D}$ and modulates its effects in colon cancer cells," Human Molecular Genetics, vol. 20, no. 23, pp. 4655-4665, 2011.

[67] S. Álvarez-Díaz, N. Valle, J. M. García et al., "Cystatin D is a candidate tumor suppressor gene induced by vitamin $\mathrm{D}$ in human colon cancer cells," The Journal of Clinical Investigation, vol. 119, no. 8, pp. 2343-2358, 2009.

[68] S. Swami, N. Raghavachari, U. R. Muller, Y. P. Bao, and D. Feldman, "Vitamin D growth inhibition of breast cancer cells: gene expression patterns assessed by cDNA microarray," Breast Cancer Research and Treatment, vol. 80, no. 1, pp. 49-62, 2003.

[69] A. Barbáchano, P. Ordóñez-Morán, J. M. García et al., "SPROUTY-2 and E-cadherin regulate reciprocally and dictate colon cancer cell tumourigenicity," Oncogene, vol. 29, no. 34, pp. 4800-4813, 2010.

[70] S. Seoane and R. Pérez-Fernández, "The vitamin D receptor represses transcription of the pituitary transcription factor Pit-1 gene without involvement of the retinoid X receptor," Molecular Endocrinology, vol. 20, no. 4, pp. 735-748, 2006.

[71] P. Kaler, V. Galea, L. Augenlicht, and L. Klampfer, "Tumor associated macrophages protect colon cancer cells from TRAILinduced apoptosis through IL-1 $\beta$-dependent stabilization of snail in tumor cells," PLoS ONE, vol. 5, no. 7, Article ID el1700, 2010.

[72] S. Christakos, P. Dhawan, D. Ajibade, B. S. Benn, J. Feng, and S. $\mathrm{S}$. Joshi, "Mechanisms involved in vitamin D mediated intestinal 
calcium absorption and in non-classical actions of vitamin D," Journal of Steroid Biochemistry and Molecular Biology, vol. 121, no. 1-2, pp. 183-187, 2010.

[73] R. A. Bartolomé, R. Barderas, S. Torres et al., "Cadherin-17 interacts with $\alpha 2 \beta 1$ integrin to regulate cell proliferation and adhesion in colorectal cancer cells causing liver metastasis," Oncogene, vol. 33, no. 13, pp. 1658-1669, 2014.

[74] W. Zheng, K. E. Wong, Z. Zhang et al., "Inactivation of the vitamin D receptor in $\mathrm{Apc}^{\mathrm{min} /+}$ mice reveals a critical role for the vitamin $\mathrm{D}$ receptor in intestinal tumor growth," International Journal of Cancer, vol. 130, no. 1, pp. 10-19, 2012.

[75] Y. G. Zhang, S. Wu, and J. Sun, "Vitamin D, vitamin D receptor, and tissue barriers," Tissue Barriers, vol. 1, no. 1, Article ID e23118, 2013.

[76] R. M. Bostick, "Effects of supplemental vitamin D and calcium on normal colon tissue and circulating biomarkers of risk for colorectal neoplasms," The Journal of Steroid Biochemistry and Molecular Biology, vol. 148, pp. 86-95, 2015.

[77] M. J. Campbell, S. Park, M. R. Uskokovic, M. I. Dawson, L. Jong, and H. P. Koeffler, "Synergistic inhibition of prostate cancer cell lines by a 19-nor hexafluoride vitamin D3 analogue and antiactivator protein 1 retinoid," British Journal of Cancer, vol. 79, no. 1, pp. 101-107, 1999.

[78] N. Lopes, J. Carvalho, C. Durães et al., "1 $1 \alpha, 25$-Dihydroxyvitamin D3 induces de novo E-cadherin expression in triplenegative breast cancer cells by CDH1-promoter demethylation," Anticancer Research, vol. 32, no. 1, pp. 249-257, 2012.

[79] Z. Kouchi, Y. Fujiwara, H. Yamaguchi, Y. Nakamura, and K. Fukami, "Phosphatidylinositol 5-phosphate 4-kinase type II $\beta$ is required for vitamin $D$ receptor-dependent E-cadherin expression in SW480 cells," Biochemical and Biophysical Research Communications, vol. 408, no. 4, pp. 523-529, 2011.

[80] R. Gniadecki, B. Gajkowska, and M. Hansen, "1,25-dihydroxyvitamin D3 stimulates the assembly of adherens junctions in keratinocytes: involvement of protein kinase C," Endocrinology, vol. 138, no. 6, pp. 2241-2248, 1997.

[81] F. Pereira, A. Barbáchano, P. K. Singh, M. J. Campbell, A. Muñoz, and M. J. Larriba, "Vitamin D has wide regulatory effects on histone demethylase genes," Cell Cycle, vol. 11, no. 6, pp. 1081-1089, 2012.

[82] G. Ferrer-Mayorga, S. Alvarez-Díaz, N. Valle et al., "Cystatin D locates in the nucleus at sites of active transcription and modulates gene and protein expression," The Journal of Biological Chemistry, vol. 290, no. 44, pp. 26533-26548, 2015.

[83] Q. Zhang, M. Han, W. Wang et al., "Downregulation of cathepsin L suppresses cancer invasion and migration by inhibiting transforming growth factor beta mediated epithelial mesenchymal transition," Oncology Reports, vol. 33, no. 4, pp. 18511859, 2015.

[84] A. Barbáchano, A. Fernández-Barral, F. Pereira et al., "SPROUTY2 represses the epithelial phenotype of colon carcinoma cells via upregulation of ZEB1 mediated by ETS1 and miR-200/miR-150," Oncogene, 2015.

[85] I. Ben-Batalla, S. Seoane, T. García-Caballero et al., "Deregulation of the Pit-1 transcription factor in human breast cancer cells promotes tumor growth and metastasis," Journal of Clinical Investigation, vol. 120, no. 12, pp. 4289-4302, 2010.

[86] J. Sendon-Lago, S. Seoane, N. Eiro et al., "Cancer progression by breast tumors with Pit-1-overexpression is blocked by inhibition of metalloproteinase (MMP)-13," Breast Cancer Research, vol. 16, no. 6, article 505, 2014.
[87] S. Pervin, M. Hewison, M. Braga et al., "Down-regulation of vitamin D receptor in mammospheres: implications for vitamin $\mathrm{D}$ resistance in breast cancer and potential for combination therapy," PLoS ONE, vol. 8, no. 1, Article ID e53287, 2013.

[88] M. A. Nieto, "The ins and outs of the epithelial to mesenchymal transition in health and disease," Annual Review of Cell and Developmental Biology, vol. 27, pp. 347-376, 2011.

[89] X. Tan, Y. Li, and Y. Liu, "Therapeutic role and potential mechanisms of active Vitamin D in renal interstitial fibrosis," Journal of Steroid Biochemistry and Molecular Biology, vol. 103, no. 3-5, pp. 491-496, 2007.

[90] X. Tan, W. He, and Y. Liu, "Combination therapy with paricalcitol and trandolapril reduces renal fibrosis in obstructive nephropathy," Kidney International, vol. 76, no. 12, pp. 12481257, 2009.

[91] S. H. Kang, S. O. Kim, K. H. Cho, J. W. Park, K. W. Yoon, and J. Y. Do, "Paricalcitol ameliorates epithelial-to-mesenchymal transition in the peritoneal mesothelium," Nephron Experimental Nephrology, vol. 126, no. 1, pp. 1-7, 2014.

[92] C. M. Hansen, L. Binderup, K. J. Hamberg, and C. Carlberg, "Vitamin D and cancer: effects of $1,25(\mathrm{OH})_{2} \mathrm{D}_{3}$ and its analogs on growth control and tumorigenesis," Frontiers in Bioscience, vol. 6, pp. D820-D848, 2001.

[93] B. Vandewalle, A. Adenis, L. Hornez, F. Revillion, and J. Lefebvre, "1,25-Dihydroxyvitamin $\mathrm{D}_{3}$ receptors in normal and malignant human colorectal tissues," Cancer Letters, vol. 86, no. 1, pp. 67-73, 1994.

[94] S. R. T. Evans, J. Nolla, J. Hanfelt, M. Shabahang, R. J. Nauta, and I. B. Shchepotin, "Vitamin D receptor expression as a predictive marker of biological behavior in human colorectal cancer," Clinical Cancer Research, vol. 4, no. 7, pp. 1591-1595, 1998.

[95] C. Peña, J. M. Garciá, J. Silva et al., "E-cadherin and vitamin D receptor regulation by SNAIL and ZEB1 in colon cancer: clinicopathological correlations," Human Molecular Genetics, vol. 14, no. 22, pp. 3361-3370, 2005.

[96] J. A. Eisman, L. J. Suva, and T. J. Martin, "Significance of 1,25-dihydroxyvitamin D3 receptor in primary breast cancers," Cancer Research, vol. 46, no. 10, pp. 5406-5408, 1986.

[97] K. W. Colston, U. Berger, and R. C. Coombes, "Possible role for vitamin $\mathrm{D}$ in controlling breast cancer cell proliferation," The Lancet, vol. 333, no. 8631, pp. 188-191, 1989.

[98] U. Berger, R. A. McClelland, P. Wilson et al., "Immunocytochemical determination of estrogen receptor, progesterone receptor, and 1,25-dihydroxyvitamin $\mathrm{D}_{3}$ receptor in breast cancer and relationship to prognosis," Cancer Research, vol. 51, no. 1, pp. 239-244, 1991.

[99] A. A. Brozyna, W. Jozwicki, Z. Janjetovic, and A. T. Slominski, "Expression of vitamin D receptor decreases during progression of pigmented skin lesions," Human Pathology, vol. 42, no. 5, pp. 618-631, 2011.

[100] W. K. Hendrickson, R. Flavin, J. L. Kasperzyk et al., "Vitamin D receptor protein expression in tumor tissue and prostate cancer progression," Journal of Clinical Oncology, vol. 29, no. 17, pp. 2378-2385, 2011.

[101] M. Srinivasan, A. V. Parwani, P. A. Hershberger, D. E. Lenzner, and J. L. Weissfeld, "Nuclear vitamin D receptor expression is associated with improved survival in non-small cell lung cancer," Journal of Steroid Biochemistry and Molecular Biology, vol. 123, no. 1-2, pp. 30-36, 2011.

[102] M. G. Anderson, M. Nakane, X. Ruan, P. E. Kroeger, and J. R. Wu-Wong, "Expression of VDR and CYP24A1 mRNA in human 
tumors," Cancer Chemotherapy and Pharmacology, vol. 57, no. 2, pp. 234-240, 2006.

[103] N. Lopes, B. Sousa, D. Martins et al., "Alterations in Vitamin D signalling and metabolic pathways in breast cancer progression: a study of VDR, CYP27B1 and CYP24A1 expression in benign and malignant breast lesions Vitamin D pathways unbalanced in breast lesions," BMC Cancer, vol. 10, article 483, 2010.

[104] M. Thill, D. Fischer, K. Kelling et al., "Expression of vitamin D receptor (VDR), cyclooxygenase-2 (COX-2) and 15-hydroxyprostaglandin dehydrogenase (15-PGDH) in benign and malignant ovarian tissue and 25-hydroxycholecalciferol $\left(25\left(\mathrm{OH}_{2}\right) \mathrm{D}_{3}\right)$ and prostaglandin $\mathrm{E}_{2}\left(\mathrm{PGE}_{2}\right)$ serum level in ovarian cancer patients," Journal of Steroid Biochemistry and Molecular Biology, vol. 121, no. 1-2, pp. 387-390, 2010.

[105] H. G. Pálmer, M. J. Larriba, J. M. García et al., “The transcription factor SNAIL represses vitamin D receptor expression and responsiveness in human colon cancer," Nature Medicine, vol. 10, no. 9, pp. 917-919, 2004.

[106] M. J. Larriba, N. Valle, H. G. Pálmer et al., "The inhibition of $\mathrm{Wnt} / \beta$-catenin signalling by $1 \alpha, 25$-dihydroxyvitamin $\mathrm{D}_{3}$ is abrogated by Snaill in human colon cancer cells," EndocrineRelated Cancer, vol. 14, no. 1, pp. 141-151, 2007.

[107] R. W. Knackstedt, V. R. Moseley, S. Sun, and M. J. Wargovich, "Vitamin D receptor and retinoid X receptor $\alpha$ status and vitamin D insufficiency in models of murine colitis," Cancer Prevention Research, vol. 6, no. 6, pp. 585-593, 2013.

[108] M. J. Larriba, E. Martín-Villar, J. M. García et al., "Snail2 cooperates with Snaill in the repression of vitamin D receptor in colon cancer," Carcinogenesis, vol. 30, no. 8, pp. 1459-1468, 2009.

[109] C. Peña, J. M. García, M. J. Larriba et al., "SNAI1 expression in colon cancer related with $C D H 1$ and $V D R$ downregulation in normal adjacent tissue," Oncogene, vol. 28, no. 49, pp. 43754385, 2009.

[110] M. K. Mittal, J. N. Myers, S. Misra, C. K. Bailey, and G. Chaudhuri, "In vivo binding to and functional repression of the VDR gene promoter by SLUG in human breast cells," Biochemical and Biophysical Research Communications, vol. 372, no. 1, pp. 30-34, 2008.

[111] H. Yang, Y. Zhang, Z. Zhou, X. Jiang, and A. Shen, "Snail-1 regulates VDR signaling and inhibits $1,25(\mathrm{OH})-\mathrm{D}_{3}$ action in osteosarcoma," European Journal of Pharmacology, vol. 670, no. 2-3, pp. 341-346, 2011.

[112] S. Bai, H. Wang, J. Shen, R. Zhou, D. A. Bushinsky, and M. J. Favus, "Elevated vitamin D receptor levels in genetic hypercalciuric stone-forming rats are associated with downregulation of snail," Journal of Bone and Mineral Research, vol. 25, no. 4, pp. 830-840, 2010.

[113] C. A. de Frutos, R. Dacquin, S. Vega, P. Jurdic, I. MachucaGayet, and M. Angela Nieto, "Snaill controls bone mass by regulating Runx2 and VDR expression during osteoblast differentiation," The EMBO Journal, vol. 28, no. 6, pp. 686-696, 2009.

[114] S. Berzal, C. González-Guerrero, S. Rayego-Mateos et al., "TNF-related weak inducer of apoptosis (TWEAK) regulates junctional proteins in tubular epithelial cells via canonical NF$\kappa \mathrm{B}$ pathway and ERK activation," Journal of Cellular Physiology, vol. 230, no. 7, pp. 1580-1593, 2015.

[115] Q. Li, Y. Gao, Z. Jia et al., "Dysregulated Krüppel-like factor 4 and vitamin $\mathrm{D}$ receptor signaling contribute to progression of hepatocellular carcinoma," Gastroenterology, vol. 143, no. 3, pp. 799.e2-810.e2, 2012.
[116] D. L. Lazarova, M. Bordonaro, and A. C. Sartorelli, "Transcriptional regulation of the vitamin $\mathrm{D}_{3}$ receptor gene by ZEB," Cell Growth and Differentiation, vol. 12, no. 6, pp. 319-326, 2001.

[117] C. Peña, J. M. García, V. García et al., “The expression levels of the transcriptional regulators p300 and CtBP modulate the correlations between SNAIL, ZEB1, E-cadherin and vitamin D receptor in human colon carcinomas," International Journal of Cancer, vol. 119, no. 9, pp. 2098-2104, 2006.

[118] S. Brabletz and T. Brabletz, "The ZEB/miR-200 feedback loopa motor of cellular plasticity in development and cancer?" The EMBO Reports, vol. 11, no. 9, pp. 670-677, 2010.

[119] S. Lamouille, D. Subramanyam, R. Blelloch, and R. Derynck, "Regulation of epithelial-mesenchymal and mesenchymalepithelial transitions by micrornas," Current Opinion in Cell Biology, vol. 25, no. 2, pp. 200-207, 2013.

[120] M. K. Jolly, M. Boareto, B. Huang et al., "Implications of the hybrid epithelial/mesenchymal phenotype in metastasis, frontiers in oncology," Frontiers in Oncology, vol. 5, article 155, 2015.

[121] O. H. Ocaña, R. Córcoles, Á. Fabra et al., "Metastatic colonization requires the repression of the epithelial-mesenchymal transition inducer Prrxl," Cancer Cell, vol. 22, no. 6, pp. 709724, 2012.

[122] J. H. Tsai, J. L. Donaher, D. A. Murphy, S. Chau, and J. Yang, "Spatiotemporal regulation of epithelial-mesenchymal transition is essential for squamous cell carcinoma metastasis," Cancer Cell, vol. 22, no. 6, pp. 725-736, 2012. 

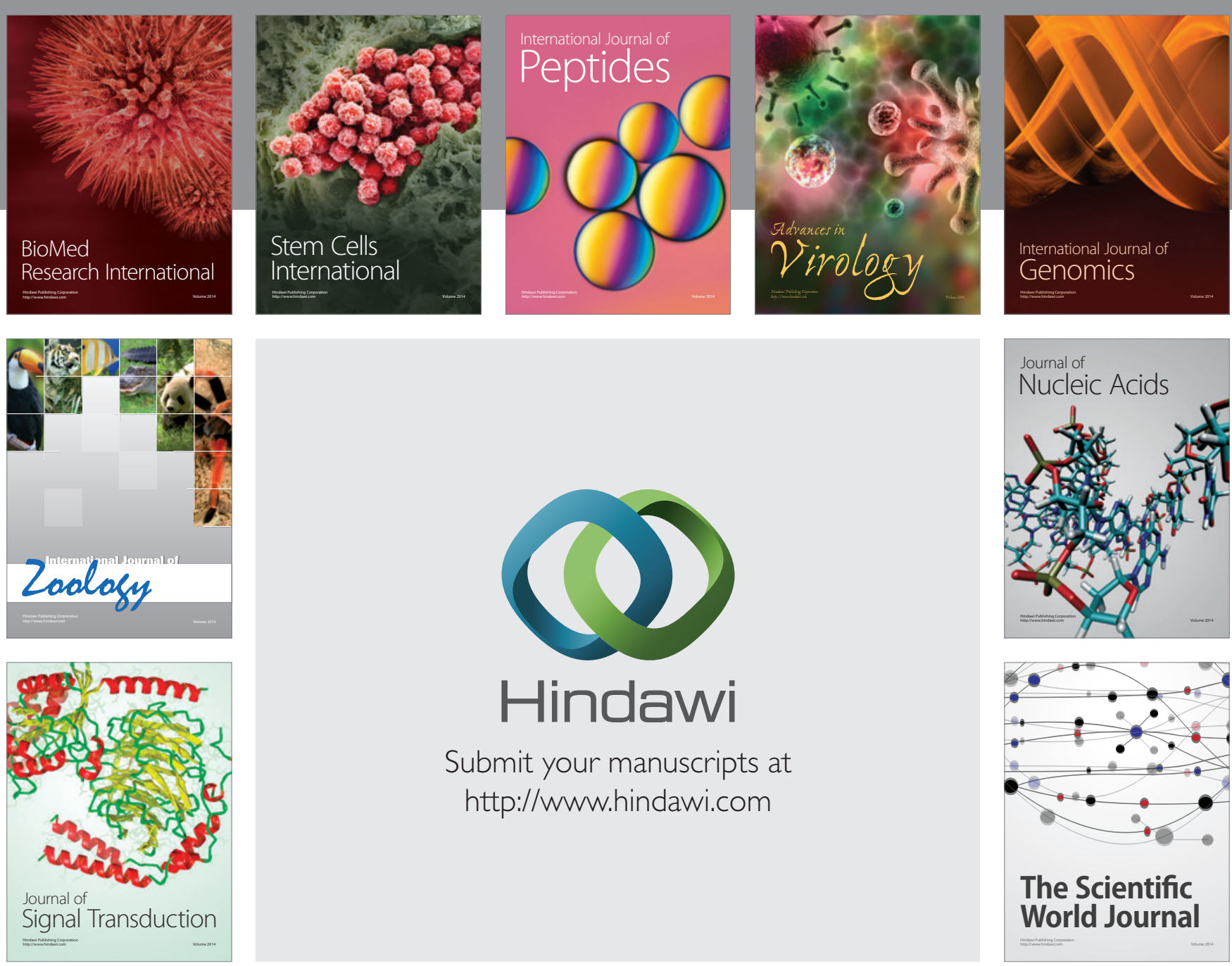

Submit your manuscripts at

http://www.hindawi.com
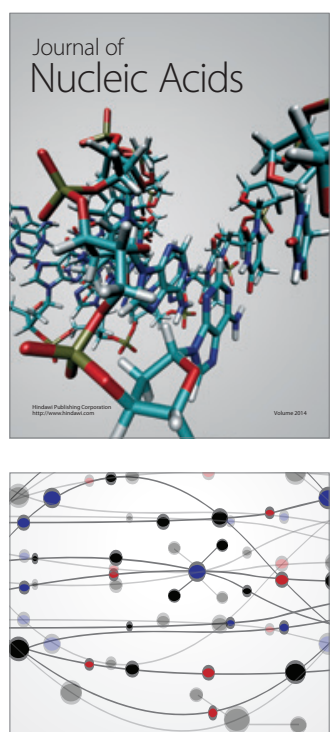

The Scientific World Journal
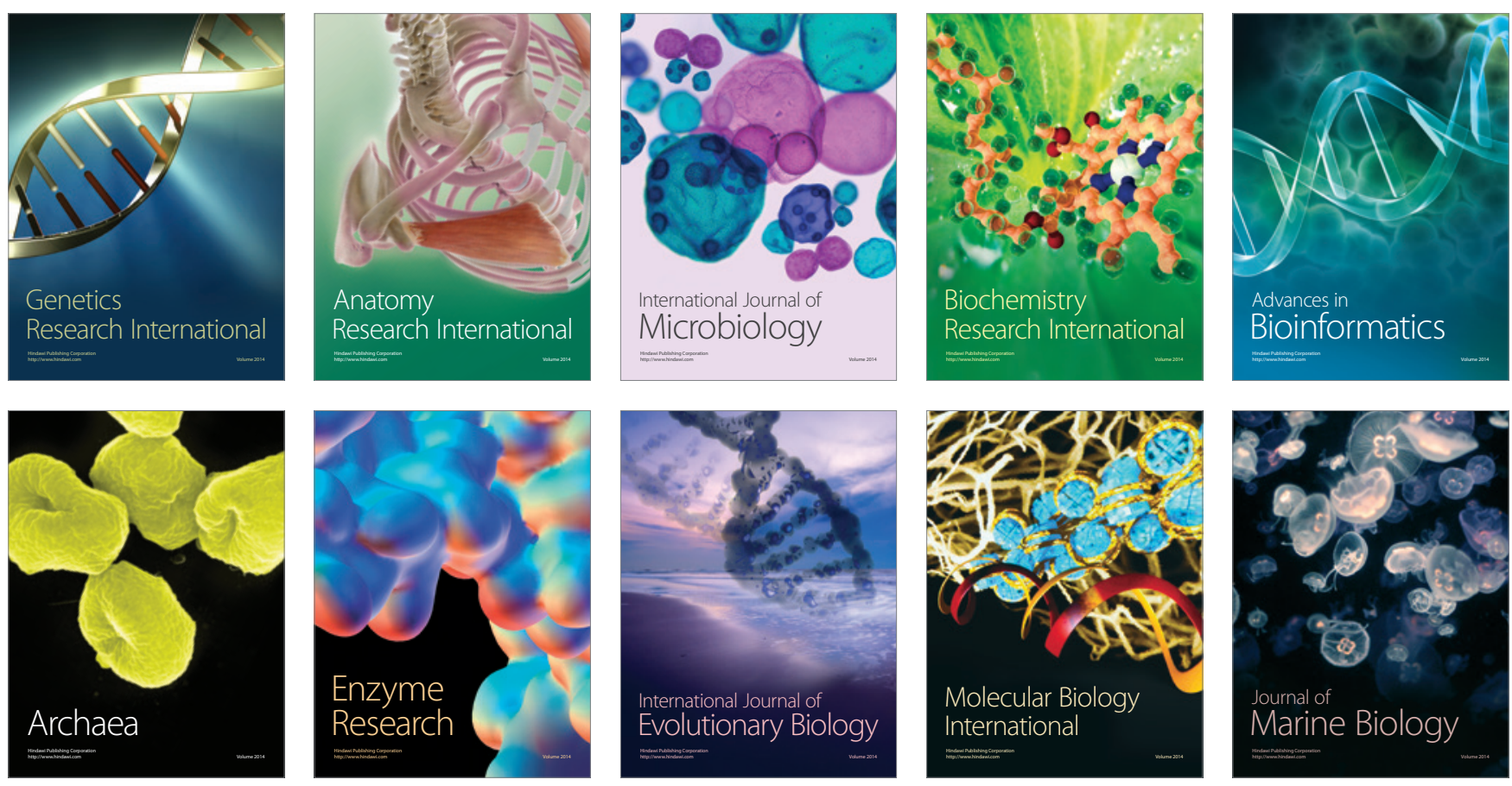